\title{
Damages and Compensation in Case of Breach of Contract
}

\author{
Mustafa Rashid Issa (Corresponding author) \\ Malaysia \\ E-mail: mustafarashidissa@yahoo.com.my
}

Received: January 1, 2015 Accepted: March 12, 2015 Published: March 26, 2015

doi:10.5296/ijssr.v3i1.6852ＵRL: http://dx.doi.org/10.5296/ijssr.v3i1.6852

\begin{abstract}
The CAS in the "Matuzalem case" determined the positive interest, the player has to compensate more than the damages which the former club actually suffered. The CAS deliberately chooses for the calculation of the indemnity a method which is unforeseeable for the football player. The European Court of Justice held in this decision that an indemnity for damages can only be calculated based on fixed criteria, i.e. criteria that are known. However, the approach of the CAS is contrary to the principle that the damage suffered is to be concretely calculated and that an indemnity may not contain any deterrent or punishing elements. According to the principles of Swiss tort law the reimbursement of damages is limited to the extent it can be expected within the usual course of affairs and the general experience of life that such damages are suitable to cause damages of the kind that actually occurred. The calculation of the compensation is to be based on the difference between the terminated and the new player's contract as well as under consideration of a compensation for acquisition costs of the former club which have not been fully amortized due to the early termination of the contract. This seems to be the one and only adequate solution to achieve the balance between the contractual stability and the freedom of movement for players, which is actually the purpose of the FIFA regulations.
\end{abstract}

Keywords: Breach of Contract, Compensation, Damages, Tort Law, Former club

\section{Introduction}

'The function of the law is to enable rights to be vindicated and to provide remedies when duties have been breached. The purpose of this article is to explore the extent to which the English courts pursue a vindicatory function when awarding a remedy for breach of contract and, in particular, to examine the function of contractual damages. Vindication describes the 
making good of the claimant's legal right by the grant of an adequate remedy. Unless an infringed right is met with an adequate remedy, the right is a hollow one, stripped of all practical force and devoid of all content. As society becomes more rights-focused and English law more rights based, the vindicatory function is likely to become increasingly evident. In this piece two related claims concerning vindication are put forward.

The first is that the English courts already recognize that their primary objective in awarding a remedy for breach of contract is the vindication of the claimant's rights under that contract. While the limited availability of specific relief and the preference for compensation as a substitute for performance suggest that contractual rights are vindicated only in a weak sense, closer examination of conventional compensatory principles reveals that compensation is very much a means to an end rather than an end in itself. That end is the making good of the claimant's right to performance of the contract. The second claim is that a discrete remedy, vindicatory damages, may be identified in contract cases. Up until the 'new start' heralded by the decision in Attorney-General v. Blake, it was commonly accepted that damages for breach of contract were exclusively loss-based.

The fundamental basis of contractual damages was to compensate 'for pecuniary loss naturally flowing from the breach'. But in Blake, the House of Lords acknowledged that English 'law does not adhere slavishly to the concept of compensation for financially measurable loss': damages may be measured by the gain made by the defendant. The precise nature of such damages has proved controversial. Some judges and commentators maintain that gain-based damages are restitutionary, others, that the damages remain compensatory. The better view, it is suggested, is that these damages are vindicatory in nature. Vindicatory damages, which to date have only been explicitly recognized in the context of constitutional rights are neither loss-based nor gain-based: they are a rights-based remedy. As well as providing a just remedy in suitable cases, vindicatory damages offer a further benefit. For at present, the concept of loss in English contract law is in danger of being over-stretched. Extending the availability of vindicatory damages to contractual actions would provide a more accurate explanation of the remedy awarded in certain cases and would help to preserve the coherence of the conventional remedies of compensation and restitution.

The following article will give an interpretation of art. 17 of the FIFA Regulations about the status and transfer of players (hereinafter "FIFA Regulations”), from a Swiss law point of view. The focus of the deliberations will be especially on the financial consequences of the termination of a contract as described under this provision. Art. 17 FIFA Regulations and its interpretation must in any event comply with mandatory Swiss law according to Article 63 para 2 of the Swiss Civil Code, because of the fact that FIFA is an association incorporated under Swiss law. Furthermore, non-mandatory Swiss law can also be relevant in relation to art. 17 FIFA Regulations. ${ }^{1}$ Hence, Swiss law is relevant for art. 17 FIFA Regulations not only since the "Webster Decision". In this ruling the CAS held that the reference in art. 17 para. 1 of the FIFA Regulation, to "the law of the country concerned" (to calculate the

\footnotetext{
${ }^{1}$ Heart of Midlothian v/ Webster \& Wigan Athletic FC CAS 2007/A/1298, 2007/A/1299, 2007/A/ 1300 (hereinafter cited as "Webster decision"), cf. also regarding the question of the applicable law the diametric considerations of the CAS in the "Matuzalem decision" under chapter 4.2
} 
compensation in case of a breach of contract), should not be misleading because according to art. 60 para. 2 of the FIFA statutes the interpretation and validity of decisions and regulations of the FIFA may only be assessed under one statute: Swiss law. ${ }^{2}$ However this approach and also the one in the "Matuzalem case" cannot be generally accepted. Apart from the applicable mandatory Swiss law, the term "the law of the country concerned" in art. 17 para. 1 of the FIFA Regulation refers to the mandatory law of the country with the closest links to the contractual relationship concerned.

Bearing these considerations in mind, this article will point out the mandatory provisions under Swiss law that a court must respect in any case where fixing an amount of compensation based on art. 17 FIFA Regulations. Further, the authors will shed light on the principles of Swiss law applicable to the calculation of compensation as foreseen in art. 17 FIFA Regulations if a court designates Swiss law as the applicable law.

\section{Firing on the Job}

According to art. 334 para. 1 CO fixed-term employment contracts end without notice at the expiry of the contracting period. If an employment relationship after this period is upheld by tacitly extending the contract, it will be deemed to be open-ended.

Fixed-term employment relationships do not exclude employers and employees agreeing on notice periods which allow an early termination of the employment relationship. If the parties have not agreed on such a notice period, only an early termination as defined in art. 337 CO is possible to end the relationship before the expiry of the contractual period. In this case regarding the financial consequences a distinction is to be made between whether the dismissal was for good cause or not (cf. chapter 3). Further it is possible that fixed-term employment relationships may be terminated based on an agreement and mutual consent of the parties to terminate the contract.

An open-ended employment relationship may be terminated by either party by respecting the contractually agreed or statutory notice periods. In Swiss labor law it is an important mandatory principle that different notice periods for employees and employers must not apply (so called parity of termination periods, cf. art. 335a CO).

Amongst Swiss scholars it is controversial (but has been affirmed several times by cantonal jurisprudence), whether from art. 335a para $1 \mathrm{CO}$ a substantial parity can be derived in the sense that also beyond the period of notice the other conditions for termination and its consequences may not be aggravated unilaterally for one party (e.g., by way of economic disadvantage $)^{3}$. Further, special regulations are to be respected regarding the termination of an employment relationship during the probation period or in case of mass redundancies.

The Swiss labor law regulates, inter alia, in art. 336 ss. CO the issue of dismissal protection. A termination is regarded as wrongful if it infringes the principle of good faith (art. 2, para 2

\footnotetext{
2 "Webster decision", recital 16 ss.

3 U. Streiff/A. von Kaenel, Arbeitsvertrag, Praxiskommentar zu Art. 319-362 OR, Zurich/Basel/ Geneva 2006, N 2 pursuant art. 335a CO, 611.
} 
CC). It is important to distinguish between a wrongful termination and a termination at an inopportune juncture. The latter involves a notice of termination during a period blocked by law (cf. art. 336c para. $1 \mathrm{CO}$ and art. 336d para. $1 \mathrm{CO}$ ). Any notice of termination during such period (for example during pregnancy or while an employee is absent due to performance of military service, sickness or accident) is void (cf. art. 336c para. 2 CO).

\section{Termination Consequences}

As a result of this provision, the employee should be treated as if no notice of termination with immediate effect had been pronounced. Hence, the so-called positive interest ${ }^{4}$ is owed to the employee. This positive interest in case of a termination with immediate effect without just cause consists of the remaining wage(s) and includes other factors like a possible 13th month wage, a severance payment, expenses etc. ${ }^{5}$ If the employee wants to claim additional damages, he is entitled to do so according to the general conditions of Swiss tort law. ${ }^{6}$ Further it is to be noted that the employee cannot require reemployment. Instead of this, the judge can oblige the employer to pay, in addition to the damages as set out above, compensation at the most of a maximum of six monthly salaries to the employee. The fixing of such compensation lies within the discretion of the judge, who has therefore to consider all circumstances which led to the resolution of the employment relationship. Some scholars qualify this kind of compensation as a penalty, ${ }^{7}$ the jurisprudence however calls it a civil law punishment. $^{8}$

By failure of the employee to take up his post or if he leaves it without notice and good cause, the employer is entitled to a compensation which corresponds to one quarter of a monthly wage of the employee (art. 337d para. 1 CO). However, if the employee produces evidence that no damages or only lower damages than this quarter of a monthly salary have occurred, the compensation has to be adapted accordingly. Nevertheless the employer has also the possibility to claim greater damages than the quarter of a monthly wage of the employee (cf. art. 337d para. 1 CO in fine). Art. 337d CO and the compensation set forth in this provision are intended to lead to a simplification of the calculation of the damages: The employer has no burden of proof regarding damages which lie within the quarter of a monthly wage of the employee. Hence, the claim for a quarter of a monthly wage may have similarities with a contractual penalty, but as a matter of fact, it is only a lump-sum indemnity. Art. 337d CO causes de facto a reversal of the burden of proof and, hence, is not to be qualified as a contractual penalty. Nevertheless, the preference of the employer by the reversal of the burden of proof reaches only so far, as it is not a bigger claim at stake than a quarter of a monthly wage of the employee. Otherwise the employer must prove the extent of the

\footnotetext{
${ }^{4}$ Cf. Decision of the Swiss Federal Supreme Court, BGE 125 III 14, 16.

5 U. Streiff/A. von Kaenel, Arbeitsvertrag, Praxiskommentar zu Art. 319-362 OR, Zurich/Basel/ Geneva 2006, N 2 pursuant art. 337c CO, 769.

${ }^{6}$ U. Streiff/A. von Kaenel, Arbeitsvertrag, Praxiskommentar zu Art. 319-362 OR, Zurich/Basel/ Geneva 2006 , N 4 pursuant art. 337c OR, 772 .

7 Cf. inter alia. U. Streiff/A. von KAenel, Arbeitsvertrag, Praxiskommentar zu Art. 319-362 OR, Zurich/Basel/Geneva 2006, N 7 pursuant art. 337c CO, 778.

8 Cf. Decision of the Swiss Federal Supreme Court, BGE 123 III 391; Pra 1999 Nr. 112, 614.
} 
damages as well as the causality between the damages claimed and the termination with immediate effect of the employee according to the general principles of tort law. Considering this, art. 44 para.

Art. 337d CO is an absolute mandatory provision. Therefore, it is not allowed to penalize the early termination of an employee with a contractual penalty. This applies not least because the legislator wanted, due to the fact that an employment relationship is strongly personality-related, to make it possible for the employee to change a job without ruinous consequences.

\section{Assessment of the CAS jurisprudence}

Following the Swiss labor law, damages of the employer due to a termination with immediate effect by an employee usually consist of the additional costs for the engagement of a temporary employee, the costs of overtime work by the other employees or the costs for outsourcing the respective work to a third party. In case of a fixed-term employment contract additionally the problem may arise that an adequate replacement must be found ahead of time. These cost items had been correctly reflected in the "de Sanctis-case" and finally made a considerable share of the compensation. ${ }^{9}$ Theoretically also loss of profit could be part of the positive interest. However, this kind of damage is very difficult to prove and therefore rarely admitted in practice. ${ }^{10}$ An analogue approach seems to be justified also in the area of football: In general it is to be assumed that the salary of a player (the employee) agreed for the entire term of the contract reflects the performance which the player/employee is able to serve. As a consequence the lapse of the duty to pay a salary will not cause any damages to the club/employer. This should apply at least if the club is not replacing the player and further the club is not able to prove any loss of damage caused by the early termination.

\section{Prevailing Difference Theory in Switzerland}

Regarding this preliminary finding some additional in-depth thoughts are to be added: According to the prevailing difference theory in Switzerland, the damage consists of the difference between the current financial status and the hypothetical state of the assets without the harmful event. As set out above, the CAS tried in the "Matuzalem case" to calculate the damages by determining the positive interest, i.e. that the injured party is to be put in the same position as if the contract would have been completely fulfilled. In our opinion, such positive interest has to be determined as follows: If the contract between the player and the club is fulfilled correctly, the club may benefit during the entire duration of the contract from the services of the player in exchange for the payment of the agreed salary. If the player's potential increases exceptionally, the salary under the actual contract might be too low compared with his performance, i.e. that if he could negotiate a new contract, most likely he would earn more than under the old contract. This means that the player's performance is de

\footnotetext{
9 “de Sanctis decsion", recital 73.

10 U. Streiff/A. von Kaenel, Arbeitsvertrag, Praxiskommentar zu Art. 319-362 OR, Zurich/Basel/ Geneva 2006 , N 6 pursuant art. 337d CO, 611 .
} 
facto underpaid and therefore the club gains a financial benefit, as he would have to pay more than he does now for another, equivalent, player. In case of an early termination of the contract, the club loses this advantage. Hence, the decisive delta for the positive interest in case of an early termination consists of the difference between the salary of the player under the old contract and the income under the new contract in consideration of the actual term left until the expiry of the contract with the former club. The actual value of the player is reflected in the salary which the new club is willing to pay to the player for his services under the new contract. The difference of this sum to the salary under the old contract reflects the increase of value of the player since the last contract negotiations until the signing of the new contract. This difference is the positive interest which the former club is not able to realize due to the breach of the contract by the player.

Of course the objection can be made that the additional value of a player under a new contract does not only consist of the delta explained above. This in particular is the case if a club is willing to pay a transfer fee for the player. In such a situation, the club does not only declare the additional value that he sees in a player through a higher salary but also by paying in addition a transfer fee to the former club. The value added to the player under the new contract according to this approach consists of the difference between the salary under the new and under the old contract as well as of, according the ruling of the CAS in the "Matuzalem case", the transfer fee paid by the new club. Under this approach one must keep in mind the following: The additional value of a player reflected in a possible transfer fee may not per se be attributed to the former club. Because whether a transfer will be realized or not, and therewith the question of whether the former club may realize a profit by way of the transfer fee, does not lie exclusively in the sphere of influence of the club. Moreover such transfer relies mostly on the willingness of the player to agree on such a transfer. As a consequence, the player may avert such a transfer fee in favour of the club not only by an early termination of the contract, but also with good right, by refusing any attempt of a transfer. Thus, a lost transfer fee may not be qualified as lost profit on behalf of the club and therefore cannot be part of the club's positive interest. Rather, this situation is to be seen as a possibility to perhaps one day realize a transfer fee and thus to be qualified as a loss of opportunity (perte d'une chance) if such opportunity, on any grounds whatsoever, finally does not materialize. The legal construction of the loss of opportunity in Switzerland is at present not recognized as a factor which could be claimed as damages. A chance itself, in case a lucrative transfer fee, cannot be qualified as an asset, neither an actual one nor a future one. Either such a chance can be realized and becomes a fully fledged asset or it will be "realized in nothing". Thus, a chance itself is never part of the wealth which can be used for the calculation of damages. ${ }^{11}$ This conclusion would only be different if the club had already negotiated a transfer in a very concrete way, but the latter would be hindered due to a breach of contract by the player. In such a case, it is to be assumed that the chance of a profit due to a transfer has already become so concrete that a recoverable damage exists. ${ }^{12}$ In all other

\footnotetext{
11 V. PRIBNow, Neuere Urteile zum Haftpflicht- und Privatversicherungsrecht, in: Personen-Schaden-Forum 2008, Zurich $2008,307$.

12 Cf. also U. HAAs, Die Rechtsprechung des CAS zur Vertragsstabilität im Verhältnis zwischen Fussballspielern und Klubs, in: Causa Sport, 3/2008, Zurich 2008, 249.
} 
situations the general possibility of a transfer fee may not be used for the calculation of damages in case of an early termination.

If one is consequently pursuing the concept of the positive interest, which means as already mentioned that the injured party is to be put in the same position as if the contract would have been completely fulfilled, the following picture is shown: the player and the club are to be put in the position as if the term of the contract had expired without any incident. Under this assumption, the player would now be free to conclude any new contract he wants to, as he is no longer bound by the old contract. Such negotiations of course could also take place with a new club and the latter would not have to pay any transfer fee at all to the old club under this situation. Therefore, if the correct fulfilment of the contract is assumed, the old club automatically loses its chance to realize any transfer fee. Thus, if the interest in the correct fulfilment of the contract is assumed, a transfer fee can never be part of the claimed damages. These two deliberations dogmatically hinder the idea that a compensation for the "lost" transfer fee can be awarded to a club due to the breach of contract by a player.

However, also the approach in the "Webster case" cannot be fully agreed from a Swiss law perspective. Dogmatically, damages cannot consist in an amount saved due to the "harmful" incident. Nevertheless it is to be borne in mind that, due to the specificity of sport, the value of the services of a player is difficult to estimate by monetary indicators, as the services of a player for a club cannot just be replaced by another equivalent player. The value of a player and therewith the damage through his loss, may most likely be measured against the amount the club was willing to effectively pay for the player's services. From this point of view, the findings in the "Webster case" are to be agreed with, however with the reservation that this way of damage calculation does not recognize any additional value of the player caused by an increase of the player's performance. In the "Matuzalem case" the CAS added for the calculation of the damages i) the services which the player would have rendered within the next two years (reflected by way of his future income) and ii) the transfer fee which would have to be paid according to his new contract. By this addition, the CAS violated the fundamental principle of tort law which says that no bigger damages are to be granted in compensation than those that were actually incurred. Further the CAS assessed the player's performance not by considering the contract with the former club, but by taking into account contracts which never had been performed, contracts with a duration until the year 2011 and also based on a salary which the player would only have received, if ever, after the expiry of the contract with his former club. Further, the CAS considered the planned contract with SS Lazio Roma (this contract has never been performed), and therefore again a possible future increase of the player's value, to calculate the compensation for his former club. By doing this, the CAS diverges from its principle that the damages to be repaired must flow from the breached contract and not from the value that a third party attributes to the services of the player, e.g. by way of a transfer fee.

Such an approach would, as RADOSTOVA/WIESCHEMANN correctly noted, lead under certain circumstances to the situation that clubs would not only be compensated but enriched, 
as depending on the transfer situation, they would profit from monetary advantages which they themselves would never have achieved. ${ }^{13}$ As a conclusion, according to the "Matuzalem decision" the player is obliged to indemnify his former club for damages which are largely based on fictitious assumptions. Further, from a Swiss law point of view the damages are compensated twice by this calculation. Apart from that, according to the strict wording of art. 17 FIFA Regulations, only compensation is due, and not damages.

\section{Cancelling the Contract by Employee with Immediate Effect}

Under the criteria "specificity of sport" the CAS in the "Matuzalem case" added the amount of EUR 600 '000 to the double indemnity. This meets approximately six monthly wages under the former contract. To justify a possible lump-sum in connection with the breach of an employment contract the CAS reverts to Art. 337c para. 3 CO and art 337d para. 1 CO and finds that six monthly wages are possible as compensation. This interpretation however clearly contradicts the wording of the cited provisions. According to art. 337c para $3 \mathrm{CO}$ the employer may be obliged by the court to pay the employee a compensation of up to six monthly wages, if he dismisses the employee without good cause. This clear wording cannot just simply be applied vice versa in favour of a football club (the employer) with the argument that a player has a relatively greater power of negotiation as a great number of clubs compete for the player. This because, on the other hand, any club has the possibility to hire football players from all over the globe and the free positions in each team are limited. Therefore the protective regulations of the labour law must also mandatorily apply to football players. In case the employee is cancelling the contract with immediate effect, art. 337d CO protects the employer from an unjustified termination. This provision entitles the employer (as part of the reparation of further damages) to a lump-sum compensation of a quarter of one monthly salary of the employee only. Thus, the maximum sum to which the player in the "Matuzalem case" could have been condemned, according to the cited Swiss law and without the proof of a bigger effective damage, is a quarter of his monthly salary, i.e. about EUR 25 '000. Further it is to be noted that this compensation cannot be claimed additionally to the damages due, but only in cases where the employer has suffered a bigger damage, which can be proved. By adding a lump-sum, the CAS has extended the compensation with a punitive element, which is not known under Swiss law. As mentioned above, the lump-sum set forth in art. 337d CO is not a contractual penalty. The CAS mistakes the legal nature of the compensation according to art. 337d CO if it declares it as a "special indemnity". ${ }^{14}$ Further, also a previous decision of the Swiss Federal Supreme Court points out that one cannot simply depart from the clear wording of art. 337c CO. In this case, a football player terminated his contract with immediate effect and with just cause after a dispute with his club. Besides the damages arising out of the loss of salary, the player also claimed an additional compensation according art. 337c para. 3 CO. With regard to this compensation, the Swiss Federal Supreme Court held, and therewith confirmed its previous jurisprudence, that this kind of compensation is only awarded to the employee, if the employer has

\footnotetext{
13 K. Radostova/C. Wieschemann, Entwicklung von Transferregeln der FIFA und der Rechtsprechung zum Schadenersatz wegen Vertragsbruches im Fußball in: Berufssportrecht, Vienna 2010, 26.

14 “Matuzalem decision", recital 156.
} 
terminated the contract without good cause. An analogue application of this provision if the employee has terminated the agreement with immediate effect and for good cause is, on the other hand, not possible. ${ }^{15}$ Finally the CAS did not take notice of the absolute mandatory nature of art. 337d CO. As already set out under chapter 3.2, one cannot deviate from this provision with the result that an early termination of the contract by the employee will be punished with a contractual penalty. But in fact this is what happened in the "Matuzalem case" when the player was condemned under the title "specificity of sport" to pay additional compensation of EUR 600'000. ${ }^{16}$

\section{An Unequal Treatment among Employer and Employee}

One of the most important principles of Swiss labor law is the principle of parity of termination periods (art. 335a CO, cf. also chapter 2.2.1.). From a substantive law point of view, the principle of parity signifies that the termination of an employment contract may not be aggravated at cost of one party by imposing economical disadvantages that would not apply to the other party. This is especially true in constellations where only one party has to pay a contractual penalty in case of the termination of a contract.

The compensation granted in the "Matuzalem case" is very similar to such a contractual penalty. The CAS in fact imposed on the player a duty to pay his former club a hypothetical wage increase, a transfer fee agreed with a third party (which has never actually been paid) and a penalty based on the specificity of sport. If the compensation is calculated in this way, a contractual penalty in the amount of a future transfer fee is imposed on the player in case of an early termination of his contract. Thus, by this practice, the contractual balance will be essentially altered at the cost of the employee. This is because a football club in the reverse situation, i.e. if the player would be dismissed before the expiry of his contract e.g. due to insufficiency, would never be forced to pay an amount which exceeds the salary to be paid to the player until the proper expiry of the contract. The way the CAS calculates the compensation leads to an unequal treatment between employer and employee and the CAS thus infringes a fundamental principle of Swiss labor law.

\section{Conclusion}

As a result of the manner in which the CAS in the "Matuzalem case" determined the positive interest, the player has to compensate more than the damages which the former club actually suffered. The CAS deliberately chooses for the calculation of the indemnity a method which is unforeseeable for the football player. This approach can no longer be upheld, at the latest since the decision of the European Court of Justice in the "Bernard" matter on March 16, 2010. ${ }^{17}$ The European Court of Justice held in this decision that an indemnity for damages ${ }^{18}$

\footnotetext{
15 Decision of the Swiss Federal Supreme Court, 4A_53/2011, recital. 2.1.1. However, it is to mention that the court although awarded by way of satisfaction and based on personal injury an amount of two monthly salaries to the player.

16 Cf. Lucien W. Valloni/Thilo Pachmann, Sports Law in Switzerland, Alphen aan den Rijn 2011, N 250.

17 Olympic Lyonnais SASP v/ Olivier Bernard and Newcastle FC, C 325/08.

18 In casu the sports and training compensation of an "espoir"-player which changed to a new club after the expiry of his traineeship were at stake.
} 
can only be calculated based on fixed criteria, i.e. criteria that are known. Further, the court held that it is inadmissible to fix the amount of the indemnity over and above the sum of damages actually suffered. ${ }^{19}$ However, the approach of the CAS is contrary to the principle that the damage suffered is to be concretely calculated and that an indemnity may not contain any deterrent or punishing elements. According to the principles of Swiss tort law the reimbursement of damages is limited to the extent it can be expected within the usual course of affairs and the general experience of life that such damages are suitable to cause damages of the kind that actually occurred. Thus the adequacy of the causality between the harming event and the damages determines which infringement of legally protected rights is to be compensated and which not. By this, the duty to compensate damages is limited. ${ }^{20}$ In other words, it must be at least abstractly foreseeable for the causer, what damages he will have to compensate. The CAS however wants the compensation, which is deemed as positive interest, to be as unforeseeable as possible, to increase the deterrent effect. Such an unforeseeable compensation has nothing to do with damages that are adequately causal. Therefore, the respective deliberations of the CAS and the consideration of punitive effects associated therewith infringe the principles of Swiss tort law outlined above. Compensation according to art. 17 FIFA regulations is therefore, not only under Community law but also under Swiss law, to be held free of any punishing elements and is to be calculated only based on the contractual value of the player. The approach that this value is to be calculated based on the remaining salary demands under the breached contract ${ }^{21}$ goes in the right direction. Nevertheless, from a dogmatic point of view only the effective increase of value of a player, which consists of the difference between the income under the former contract and the salary fixed in the new contract, must be considered as damages to the former club of the player. Thus, it would be desirable, at least from the players' view, if the CAS would go back to the direction taken in the deliberations in the "Webster case". However, transfer fees in connection with the new contract are by no means to be considered for the calculation of damages. The calculation of the compensation is to be based on the difference between the terminated and the new player's contract as well as under consideration of a compensation for acquisition costs of the former club which have not been fully amortized due to the early termination of the contract. This seems to be the one and only adequate solution to achieve the balance between the contractual stability and the freedom of movement for players, which is actually the purpose of the FIFA regulations.

\section{Reference}

Albert, D. V. (2003). La terminación de los contratos de distribución, 8 Advocatus.

Bar-Gill, O., \& Ben-Shahar, O. (2004). The Law of Duress and the Economics of Credible Threats. The Journal of Legal Studies, 33(2), 391-430. http://dx.doi.org/10.1086/421574

Beales, J. H., \& Muris, T. J. (1995). The foundations of franchise regulation: Issues and

19 Olympic Lyonnais SASP v/ Olivier Bernard und Newcastle FC, C 325/08, recital 46 ss. ।

20 I. SCHwENZER, Schweizerisches Obligationenrecht Allgemeiner Teil, Bern 2006, 4. Ed., N 19.05 s.

21 K. Radostova/C. Wieschemann, Entwicklung von Transferregeln der FIFA und der Rechtsprechung zum Schadenersatz wegen Vertragsbruches im Fußball, in: Berufssportrecht, Vienna 2010, 34. 
$\begin{array}{lllll}\text { evidence. Journal of } \quad \text { Corporate } & \text { Finance, } & \text { 2(1), }\end{array}$ http://dx.doi.org/10.1016/0929-1199(95)00008-V

Ben-Shahar, O. (2004). Agreeing to disagree: Filling gaps in deliberately incomplete contracts. Wis. L. Rev., 389.

Bercovitz, J. (1999). An analysis of the contract provisions in business-format franchise agreements. In Franchising beyond the millenium: Learning lessons from the past, Proceedings, 13th Conference of the Society of Franchising.

Bianca, C. M., \& Grundmann, S. (2002). EU Sales Directive. Intersentia nv.

Chung, T. Y. (1991). Incomplete contracts, specific investments, and risk sharing. The Review of Economic Studies, 58(5), 1031-1042. http://dx.doi.org/10.2307/2297950

Craswell, R. (1991), Passing on the Costs of Legal Rules: Efficiency and Distribution in Buyer-Seller Relationships, 43 STAN. L. REV., 361, 363

Edlin, A. S. (1996). Cadillac contracts and up-front payments: Efficient investment under expectation damages. Journal of Law, Economics, and Organization, 12(1), 98-118. http://dx.doi.org/10.1093/oxfordjournals.jleo.a023363

Goyder, J. (2005). EU Distribution Law (4th ed.). Hart Publishing, Oxford and Portland (OR)

Hermalin, B., Katz, A., \& Craswell, R. (2006). Law and Economics of Contracts. In A. M. POLINSKY \& S. SHAVELL (eds.), The Handbook of Law and Economics. North Holland (2006).

Klick, J., Kobayashi, B., \& Ribstein, L. (2006). Incomplete Contracts and Opportunism in Franchising Arrangements: The Role of Termination Clauses. Working Paper, George Mason University School of Law

Klein, B., \& Leffler, K. B. (1981). The role of market forces in assuring contractual performance. The Journal of Political Economy, 615-641. http://dx.doi.org/10.1086/260996

Kreps, D. (1990). Corporate Culture and Economic Theory. In ALT \& SHEPSLE (Eds.), Perspectives in Positive Political Economy. Cambridge University Press.

Lazear, E. (1998). Personnel Economics for Managers. John Wiley \& Sons, New York.

MacLeod, W. B., \& Malcomson, J. M. (1993). Investments, holdup, and the form of market contracts. The American Economic Review, 811-837.

Maskin, E., \& Moore, J. (1999). Implementation and renegotiation. Review of Economic studies, 39-56. http://dx.doi.org/10.1111/1467-937X.00077

Mathewson, G. F., \& Winter, R. A. (1985). The economics of franchise contracts. Journal of Law and Economics, 503-526. http://dx.doi.org/10.1086/467099

Nöldeke, G., \& Schmidt, K. M. (1995). Option contracts and renegotiation: a solution to the hold-up problem. The RAND Journal of Economics, 163-179. 
http://dx.doi.org/10.2307/2555911 2015, Vol. 3, No. 1

Paz-Ares, C. (1997). La indemnización por clientela en el contrato de concesión. La Ley, 1-816.

Polinsky, A. M., \& Shavell, S. (1993). Should Liability Be Based on the Harm to the Victim or the Gain to the Injurer? (No. w4586). National Bureau of Economic Research.

Posner, E. A., \& Triantis, G. G. (2001, September). Covenants Not to Compete from an Incomplete Contract Perspective. University of Chicago Law School, Law and Economics Workshop.

\section{Copyright Disclaimer}

Copyright for this article is retained by the author(s), with first publication rights granted to the journal.

This is an open-access article distributed under the terms and conditions of the Creative Commons Attribution license (http://creativecommons.org/licenses/by/3.0/). 